\title{
SECONDARY HYPOGAMMAGLOBILINEMIA AFTER USE OF CARBAMAZEPINE: CASE REPORT AND REVIEW
}

\author{
Ana Paula B Moschione Castro, Maria das Graças Redmershi, \\ Antonio Carlos Pastorino, José Albino da Paz, Angela Bueno Ferraz Fomin and \\ Cristina Miuki Abe Jacob
}

RHCFAP/3060

CASTRO APBM et al. - Secondary hypogammaglobilinemia after use of Carbamazepine:- case report and review. Rev. Hosp. Clín. Fac. Med. S. Paulo 56(6):189-192, 2001.

Immunologic disorders related to anticonvulsant therapy have been described in the last three decades, including cellular and humoral alterations that result in recurrent infections; however, the physiopathologic mechanisms are not completely understood.

This report describes a patient with complex partial epilepsy and hypogammaglobulinemia while in treatment with carbamazepine, with significant improvement in clinical signs and laboratory tests after substitution to sodium valproate.

The authors stress the importance of clinical and laboratory evaluation of patients in continuous anticonvulsant therapy, including immunoglobulins levels and peripheral blood evaluations.

DESCRIPTORS: Epilepsy. Immunodeficiency. Carbamazepine. Immunoglobulin. Anticonvulsant therapy.

The efficacy of carbamazepine (CBZ) for patients with epilepsy was first demonstrated in the early 1960s. In 1974, CBZ was first used in the United States as an anti-epileptic drug for adult patients with epilepsy and was approved for children 6 years of age and older. In 1987, CBZ was approved for the entire pediatric age range.

CBZ is currently used for the treatment of simple or complex epileptic seizures and for generalized tonic-clonic seizures. It is considered a major broadprescription anticonvulsant because it produces fewer behavioral or psychological disorders than phenytoin or phenobarbital ${ }^{1}$. Among the side effects of the drug most often reported are sleep disorders, anorexia, nausea, vomiting, polydipsia, irritability, ataxia, and diplo- pia. Involvement of the immune system is demonstrated by reports of dermatitis, eosinophilia, lymphadenopathy, and splenomegaly. Approximately $10 \%$ of patients develop transitory leukopenia, which usually resolves after an average of 4 months of continued treatment, while $2 \%$ of these patients develop persistent leukopenia requiring discontinuation of the drug${ }^{2}$.

Involvement of the immune system has been studied since the drug was first used, and according to Sorrel and Forbes $^{3}$, affects as many as $47 \%$ of the patients treated with CBZ. Among the changes described are IgA and IgM de-

From the Children's Institute, Hospital das Clínicas, Faculty of Medicine, University of São Paulo. ficiency, and reduced DNA and RNA synthesis in circulating leukocytes and in cultured lymphocytes stimulated with phytohemagglutinin (PHA) ${ }^{3}$. Decreased serum IgG levels have been reported in a few studies and in isolated clinical cases $^{4-7}$, with the reduction in IgA being the change most commonly noted $^{3,8-11}$.

The physiopathological mechanisms of the side effects of the drug on the immune system have not been fully elucidated, but they do not seem to depend on the dose or on the serum concentration of the drug, or on the duration of treatment ${ }^{3}$.

We report here a patient with complex partial epilepsy who presented hypogammaglobulinemia after beginning treatment with $\mathrm{CBZ}$ and who 
showed clinical and laboratory improvement after the drug was replaced with valproic acid.

\section{CASE REPORT}

A 7-year-old boy followed on an ambulatory basis because of moderate asthma and allergic rhinitis, which had started at 1 year and 6 months of age and had been clinically controlled after 3 years, had been free of repeated infections up to the age of 6 years. Laboratory tests carried out at the beginning of ambulatory follow-up showed normal $\operatorname{IgA}$ and $\operatorname{IgM}$ levels, elevated IgE levels, and a blood count with moderate eosinophilia (9\%), compatible with the atopic picture. The parents denied a family history of immunodeficiency, epilepsy, or consanguinity.

At 6 years of age the patient started to have recurrent complex partial epileptic seizures, with a personal history of fever-induced convulsions at 18 months of age and absence of impairment of neuropsychomotor development. On evaluation by a neuropediatrician, he presented focal irritative occipitotemporal activity on the right in the encephalogram and normal skull computed tomography and nuclear magnetic resonance of the nervous system. Epilepsy was diagnosed, and treatment with carbamazepine was started (400 mg/day). After 1 month of continued CBZ use, the patient started to have recurrent infections - about 9 episodes of sinusitis in 18 months requiring prolonged antibiotic treatment. The blood counts performed during this period did not show significant leukocyte changes but did reveal an increase to $25 \%$ in eosinophilia (1500/ $\left.\mathrm{mm}^{3}\right)$. The occurrence of repeated infections motivated a new immunoglobulin determination 8 months after the introduction of CBZ, which showed a significant reduction in $\operatorname{IgA}$ levels from 100 to $16 \mathrm{mg} / \mathrm{dL}$ and in
IgG levels from 1038 to $594 \mathrm{mg} / \mathrm{dL}$, and maintenance of IgM levels (Fig. 1). Serum levels of the IgG subclasses showed a preponderant fall in $\mathrm{IgG}_{2}$ to $82 \mathrm{mg} / \mathrm{dL}$ (normal range: 119 to 480 $\mathrm{mg} / \mathrm{dL}$ ). The evaluation of IgM antibodies by isohemagglutinin determina- tion was found to be normal, and evaluation of functional IgG by measles serology was negative. Cellular immunity investigated by white cell count, CD4/CD8 count, and lymphocyte proliferation after stimulation with PHA was normal.

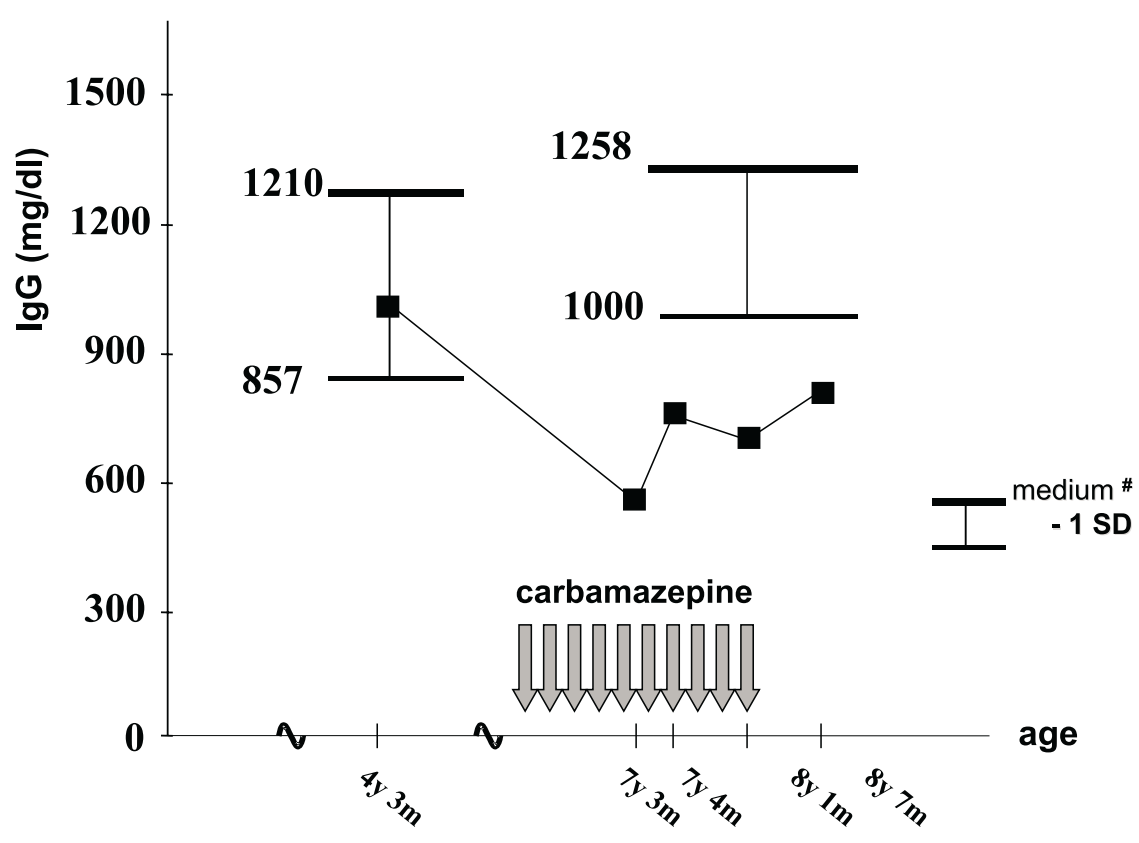

Figure 1 - IgG seric levels before, during and after carbamazepine. \# - Normal ranges of Brazilian children - Naspitz et al., J Ped, 52(3): 1982.

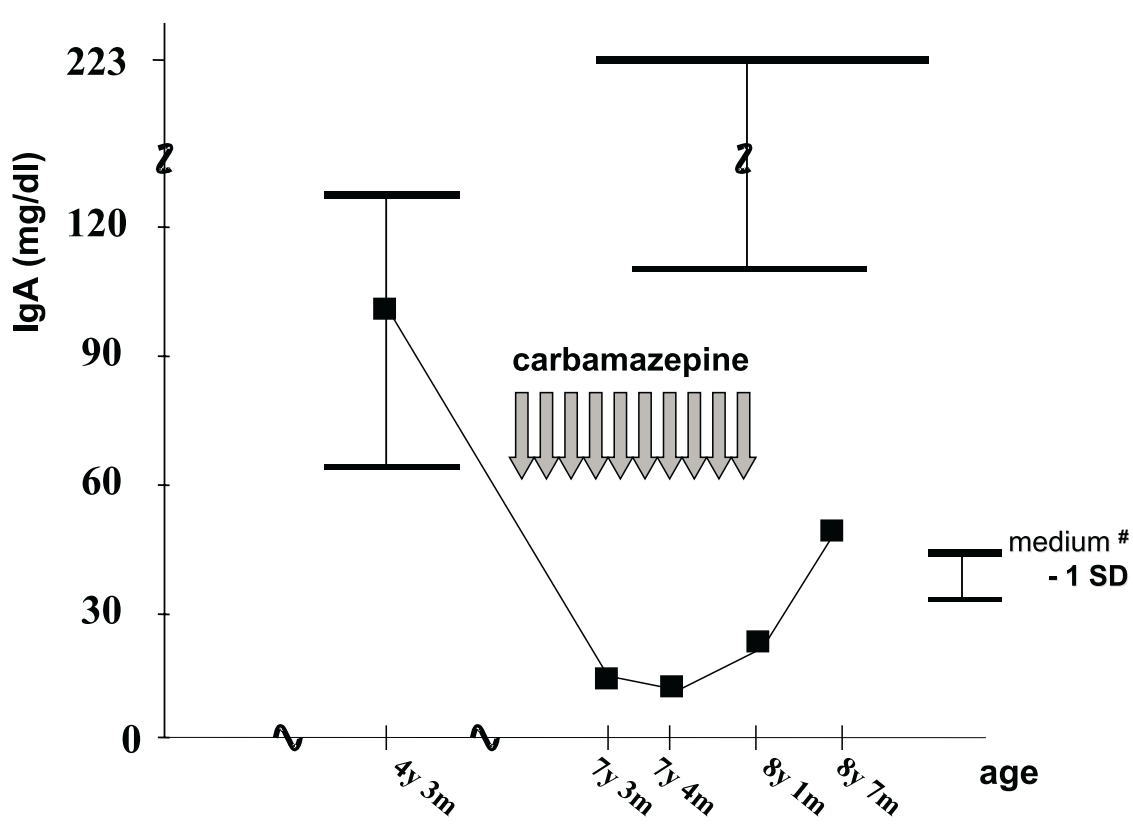

Figure 2 - IgA seric levels before, during and after carbamazepine. \# - Normal ranges of Brazilian children - Naspitz et al., J Ped, 52(3): 1982. 
CBZ was replaced with valproic acid, and 8 months after the discontinuation of $\mathrm{CBZ}$, there was a reduction in the episodes of sinusitis, and no other airway infections were observed. An increase in serum IgA and IgG levels occurred in parallel, with no need for other therapeutic measures.

\section{DISCUSSION}

The immunologic changes observed in patients treated with anticonvulsants deserve consideration because of their frequency and possible clinical repercussions.

Although phenytoin is the drug most extensively studied because of its frequent effects on the immune system, other anticonvulsants can also have similar effects, as observed in the specific case in question in which hypogammaglobulinemia developed after the use of CBZ.

After the approval of the use of CBZ for the treatment of convulsive seizures in 1974, several studies have evaluated the repercussions of this medication on the immune system ${ }^{3-16}$. The alterations in cellular immunity have been extensively studied ${ }^{3}$, but the serum concentration and function of immunoglobulins still receives special attention in the literature. Few studies have evaluated the exclusive participation of CBZ in the genesis of changes in the immune system, since convulsive patients are often undergoing multidrug therapy, including phenytoin, a fact that prevents conclusions about this matter. In addition, when the relationship of CBZ to immunoglobulin levels is evaluated, data from the literature are often contradictory. The reduction in serum IgA levels is the change most frequently reported after the use of anticonvulsants, with total and partial immunodeficiency having been reported ${ }^{3,8,9-11}$. Symptoms similar to those of patients with primary $\operatorname{IgA}$ deficiency may arise in these patients, such as recurrent infections, greater prevalence of atopy, autoimmune diseases such as systemic lupus erythematosus, and lymphoproliferative diseases such as lymphomas ${ }^{11}$. Gilhus et al..$^{9,11-}$ ${ }^{14}$ concluded that the immunologic alterations presented by epileptic patients may be related to the use of anticonvulsants rather than being secondary to the base disease. However, some authors suggest an association between epilepsy and changes in the immune system, a fact that impairs the establishment of a causative relation ${ }^{16}$. The patient reported here did not present signs or symptoms suggestive of immunodeficiency before the introduction of CBZ, and his serum IgM, IgG, and IgA levels were normal. The subsequent reduction of these last two immunoglobulins, which are fundamental for protection against infections, suggests the occurrence of immunodeficiency secondary to the anticonvulsant.

The reduction in immunoglobulin levels induced by the use of anticonvulsants may be genetically determined. There are studies showing an important relation between some types of HLA and the immunoglobulin deficiency induced by this agent. HLA-A 2 is related to the IgA deficiency induced by phenytoin, and HLA-A B may be related to the reduction in immunoglobulin levels produced by $\mathrm{CBZ}^{12,15}$.

The reduction in serum IgG by the use of anticonvulsants is a controversial matter in the literature. Most of the studies on the immunologic behavior of CBZ users reported no variations in IgG levels, but rather a decrease in serum IgA and IgM levels ${ }^{3,8-11}$, with few reports of changes in IgG concentrations related to $\mathrm{CBZ}$ use $\mathrm{e}^{4-7}$.

The mechanism by which anticonvulsants interfere with the immune system is not understood. Spickett et al. ${ }^{5}$ suggested the occurrence of interactions between cells of the central nerv- ous system and the immune system associated with the use of anticonvulsants, with no elucidation of the physiopathological process involved. Even the causes of leukopenia, the most frequent immunologic alteration, are not fully defined. However, Gilhus and Matre ${ }^{13}$ evaluated 10 patients undergoing treatment with CBZ and observed that those presenting reduced serum $\operatorname{Ig} \mathrm{A}$ and $\operatorname{IgM}$ had no reduction in the number of $\mathrm{T}$ or B lymphocytes or in their proliferating ability, suggesting a defect in B lymphocyte maturation or in immunoglobulin synthesis. In cases progressing to leukopenia or a fall in T lymphocytes with hypogammaglobulinemia, this humoral deficiency may be due to the reduction of $\mathrm{B}$ lymphocyte activation by $\mathrm{T}$ lymphocytes.

In the studies reviewed, no correlation was observed between the immunologic changes and the serum concentration of the drug or the combined use of other anticonvulsants ${ }^{2-6}$.

Andersen et al. ${ }^{4}$ reported a more marked reduction in $\mathrm{IgG}$ and $\mathrm{IgA}$ in females compared to males.

The recovery of serum immunoglobulin levels usually occurs 4 months to 6 years after the discontinuation of anticonvulsant medication ${ }^{11}$. In the present case, a progressive increase in serum $\operatorname{IgA}$ and $\operatorname{IgG}$ levels towards normal limits occurred 8 months after withdrawal of CBZ, coinciding with a decreased occurrence of infections. According to Schiff, IgG values higher than $500 \mathrm{mg} / \mathrm{dL}$ are considered to be protective in patients with a gammaglobulinemia who receive intravenous gammaglobulin replacement, a fact that considerably reduces the recurrence of infections.

CBZ continues to be the drug of first choice for the treatment of partial epilepsy, but some precautions should be taken. The present reports calls attention to the need for clinical and laboratory follow-up of CBZ users 
since changes in the immune system lead to an increased prevalence of infections, autoimmune, and even neo- plastic diseases. The professionals who habitually prescribe anticonvulsants and CBZ in particular - should be alert to these changes, and when they occur, specific immunologic evaluation should be requested ${ }^{17}$.
CASTRO APBM e col. - Hipogamaglobulinemia secundária ao uso de Carbamazepina: apresentação de caso clínico e revisão da literatura.

Rev. Hosp. Clín. Fac. Med. S. Paulo 56(6):189-192, 2001.

As alterações imunológicas relacionadas ao uso de anti-convulsivantes têm sido descrita há três décadas, en- volvendo alterações celulares e humorais, sendo os mecanismos fisiopatológicos ainda não totalmente elucidados.

Este relato descreve o caso de paciente portador de epilepsia parcial complexa com hipogamaglobulinemia durante o tratamento com carbamazepina, tendo apresentado melhora clínica e laboratorial importantes após substituição da droga pelo ácido valpróico.
Os autores ressaltam a importância do acompanhamento clínico e laboratorial, incluindo avaliação dos níveis de imunoglobulinas e hemogramas seriados dos pacientes em uso contínuo de anticonvulsivantes.

DESCRIPTORES: Epilepsia. Imunodeficiência. Carbamazepina. Imunoglobulinas. Anticonvulsivantes.

\section{REFERENCES}

1. LOISEAU P \& DUCHR B - Carbamazepine Clinical Use. In: LEVY RH, MOTTSON RH \& MELDRON BS - Antiepileptic Drugs $4^{\text {th }}$ ed New York, Raven Press, 1995. p. 555-566.

2. HARDAN JG, GILMAN AG, LIMBIRD L E et al. - Drugs effective in the therapy of the epilepsy. In: GILMAN AG - Goodman and Gilman's the pharmacological basis of therapeutics. $9^{\text {th }} \mathrm{ed}$, New York, MC Graw-Hill, 1996. p. 461-486.

3. SORREL TC \& FORBES IJ - Depression of immune competence by phenytoin and carbamazepine. Clin Exp Immunol 1975;20:273285 .

4. ANDERSEN P \& MOSEKILDE L - Immunoglobulin levels and autoantibodies in epileptics on long-term anticonvulsant therapy. Acta Med Scand 1977;201:69-74.

5. SPICKET GP \& GOMPELS MM - Hypogammaglobulinemia with absent B lymphocytes and agranulocytosis after carbamazepine treatment. J Neurol Neurosurg Psychiatry 1996;60:459-462.

6. ISHIZAKA A, NAKANISHI M, KASAHARA E et al. - Phenytoininduced $\mathrm{IgG}_{2}$ and $\mathrm{IgG}_{4}$ deficiencies in a patient with epilepsy. Acta Paediatr 1992;81:646-648.

7. MADRIGAL DIEZ V, ALONSO PALACIO J, MANJON-CABEZA AR et al. - Carbamacepina: intolerância grave con neumonía intersticial, fiebre, exantema y déficit de inmunoglobulinas. An Esp Pediatr 1993;38:190-192.

8. RUFF ME, PINCUS L G \& SAMPSON HA - Phenytoin-induced IgA depression. AJDC, 1987;14:858-861.

9. GILHUS N E, JORD R ES \& AARLI J A - The effect of carbamazepine on serum immunoglobulin concentrations. Acta Neurol Scand 1982;66:172-179.
10. SLAVIN BN, FENTON GM, LAUNDY M et al. - Serum immunoglobulins in epilepsy. J Neurol Sci 1974;23:353-357.

11. GILHUS NE \& AARLI JA - The reversibility of phenytoin-induced IgA deficiency. J Neurol 1981;226:56-61.

12. GUILHUS NE, AARLI JA \& THORSBY E - HLA antigens in epileptic patients with drug-induced immunodeficiency. Int J Immunopharmac 1982;4:517-520.

13. GILHUS NE \& MATRE R - Carbamazepine effects on mononuclear blood cells in epileptic patients. Acta Neurol Scand 1986;74:181185 .

14. GILHUS NE, STRANDYORD RE \& AARLI JA - Respiratory diseases in patients with epilepsy on single drug therapy with carbamazepine or phenobarbital. Eur Neurol 1982;21:284-288.

15. SHAKIR RA, BEHAN PO, DICK H et al. - Metabolism of immunoglobulin A, lymphocyte function, and histocompatibility antigens in patients on anticonvulsants. J Neurol Neurosurg Psychiatry 1978;41:307-311.

16. MATSUOKA H, OKADA J, TAKAHACHI T et al. - Immunological study of IgA deficiency during anticonvulsant therapy in epileptic patients. Clin Exp Immunol 1985; 53:423-428.

17. SCHUFF RJ - Treatment of primary immunodeficiency diseases with Gammaglobulin. In: LEE M \& STRAND V - Intravenous Immunoglubulin in Clinical Practice. New York, Marcel Dekker, 1997. p. 175-192.

Received for publication on November 29, 2000. 